\title{
A hazai gépkocsivezetôk beépített GPS használati szokásai - javaslat egy új navigációs felhasználói felületre
}

\author{
Vörös Fanni - Kovács Béla
}

DOI: https://doi.org/10.30921/GK.71.2019.6.3

\begin{abstract}
Absztrakt: A személyi szállitás fontos eleme az útvonal bizonyos szempontok (utazás hossza, ideje) szerinti megtervezése, föleg akkor, ha addig ismeretlen területen történik. Vannak még, akik a tradicionális, papíralapú térképeket használják, ám manapság a legtöbben valamilyen elektronikus rendszer (PDA/PNA, telefonos applikáció vagy beépített autós navigációs rendszer) segítségével navigálnak. Az autós közlekedésben természetesen másmilyen eszközökre van szükség, mint pl. a gyalogosban (a nagyobb sebesség gyorsabb reakcióidöt kíván), így a különbözö célra létrejött készülékek megjelenése és felhasználói felülete is különbözô. Több gyártó van jelenleg a piacon, amelyek autós beépített navigációs eszközöket fejlesztenek - a kutatásunkban arra voltunk kíváncsiak, hogy ezek mennyire a felhasználók (gépkocsivezetôk) igényei szerint vannak felépítve. Ahhoz, hogy ezt megvizsgálhassuk, létrehoztunk egy netes kérdöivet (Google Form), amelyet terjesztve több mint 1000 magyarországi felhasználó kitöltéséhez jutottunk hozzá. A kérdôivben rákérdeztünk a vezetôk autós navigációs rendszerrel kapcsolatos használati szokásaira, illetve a válaszok alapján létrehoztunk egy „ideális” felhasználói felületet: a kitöltók megadták, hogy ha maguk állíthatnák össze, akkor milyen funkciókat/gombokat szeretnének látni a saját navigációs rendszerükön.
\end{abstract}

Abstract: An important element of personal transport is the planning of the route according to certain aspects (journey time and distance), especially when it is in an area that has not been known before. There are others who use traditional paper-based maps, but nowadays most people navigate using electronic systems (PDA / PNA, telephone application or built-in car navigation system). Of course, in car traffic other devices needed than pedestrian traffic-higher speeds require faster response times - so devices designed for different purposes have a different appearance and user interface. There are many manufacturers/developers on the market today that make in-car GPSs - in our research we were curious about how much they are built according to the needs of the users (drivers). In order to investigate this, we created an online questionnaire (Google Form) and more than 1000 Hungarians completed it. In the questionnaire we asked drivers about their in-built car navigation usage habits, and based on the answers, we created an "ideal" user interface: the fillers stated that if they could set it up themselves, what features/buttons they would like to see on their own navigation system.

Kulcsszavak: beépített autós navigáció, kérdőív, GPS-használat

Keywords: in-built car navigation, questionnaire, GPS usage

\section{Bevezetés}

Amióta az emberben felmerült az igény a helyének megváltoztatására, fontos szempont annak milyensége: milyen rövid, milyen gazdaságos, milyen látványos az adott útvonal. Kezdetben szóbeli, vagy esetleg írásbeli (grafikus) utasítások segítették az utazót céljának elérésében. Ahogy változtak a közlekedési eszközök, úgy változtak az elvárások is a navigációs berendezésekkel szemben. Az egyre gyorsuló élet a gyorsabb és automatizáltabb eszközök igényét vetítette elô. Manapság a legtöbben a mobiltelefonjukat használják navigáláshoz, de - természetesen - az okostelefonok megjelenése elôtt is léteztek „elektronikus” navigációs készülékek.

A gépkocsik elterjedésével megjelentek az autóba épített navigációs eszközök is: az elsố ilyen mindössze 100 évvel ezelôtt, 1909-ben jelent meg (The
Automobile 1909). Azóta a beépített GPS-ek nagy változáson mentek keresztül, de a céljuk ugyanaz maradt: támogatni a sofốrt abban, hogy a lehetô legjobb úton menjen A-ból B-be. Ahhoz, hogy erról az optimális útvonalról az információ eljusson a felhasználóhoz, bizonyos időközönként a sofốrnek rá kell pillantania, adott esetben használnia is kell a kezelófelületet. A biztonságos vezetés érdekében ez a rápillantás néhány másodpercnél nem tarthat tovább. A beépített navigációs rendszereknek lehetôségük van arra, hogy összetett módon befolyásolják a felhasználók és környezetük viszonyát. Az empirikus és elméleti elemzések azt mutatják, hogy a GPS-ek használata megváltoztatja az emberek körülötti világ értelmezését, tanulási szokásaikat, navigálási technikájukat, a terek és helyek megismerését (Leshed et al. 2008). Ebbốl is látható, hogy menynyire fontos a megfelelố mennyiségú és minôségú gomb/funkció/információ elhelyezése a kijelzôn. Ahány fejlesztő, annyiféle felület létezik, de persze vannak azonosságok. Ezek megvizsgálása felhasználói szempontból segíthet eldönteni, hogy a sofôrök elégedettek-e az aktuális beépített eszközükkel, és ha nem, akkor milyen funkciók segíthetnek jobbá tenni ezeket a készülékeket.

\section{A kérdôív}

Magyarországon a témában egyetlen tanulmányt publikáltak, 8 évvel ezelőtt. A 153 kérdésre 109 ember adott választ (Varga 2011). A külföldi szakirodalomban is szegényes ennek a témakörnek a feldolgozottsága: Al Mahmud 2009es publikációjában 15 megkérdezettrôl ír, akik mind TomTom navigációt használtak.

Ahhoz, hogy a lehetô legtöbb emberhez eljuthassunk, egy netes kérdő́ivet 
hoztunk létre, egy Google Formot, amely a legtöbb felhasználó számára ismerôs lehetett.

Három részre bontható a kérdőív, amelyet a gépkocsivezetôkkel töltettünk ki. Az elsô 17 kérdés általános jellegú, és mindenkinek kötelező volt megválaszolni - például korra, nemre, végzettségre kérdeztünk rá, de vezetési szokásaik is érdekeltek minket. Ezen rész utolsó kérdésére (Használja a beépitett navigációt?) adott választól függött, hogy a kitöltő ezután mely kérdéssort kapta meg. Ha nincs, vagy nem használja a beépített GPS-t, akkor mindössze 3 további kérdést tettünk fel; ebben a cikkben ezekkel nem fogunk foglalkozni. $16+12+2$ kérdés várt azokra, akik használnak beépített navigációt. Ezekben általánosabb dolgokra, részletekbe menố információkra és arra kérdeztünk rá, mit lát és mit szeretne látni a kitöltő az eszközének „térkép” nézetén.

\section{Eredmények}

A kérdőív két hónapig (2018. december elejétôl 2019. január végéig) volt elérhetô az interneten. Az összes kitöltônek (több mint 1000) a 10\%-a használ beépített navigációt, így $\sim 100$ ember válaszai alapján dolgoztunk ebbôl adódóan minden eredményt nem tudunk most bemutatni, csak néhány kiválasztott témán keresztül fogjuk felvillantani, hogy milyen jellegű kérdéseket tettünk fel.

Kíváncsiak voltunk rá, hogy a különböző vezetési helyzetek menynyiben befolyásolják azt, hogy a sofőrök milyen gyakran használják a beépített navigációjukat, így létrehoztunk 8 vezetési szituációt. A 2 . ábrán látható, hogy a legtöbben a mindennapos útjaiknál mellốzik a navigációs eszköz használatát, míg az ismeretlenebb környezetben, illetve külföldön sokkal többször kapcsolják azt be.

A GPS-ek nagy részének (73\%) adatbeviteli módja érintőképernyôs (touchscreen), 26\%-uk „tekerôs” (navigation knob) és mindösszesen 1\%-uk múködik csak hangvezérléssel. Az összes eszközt figyelembe véve 36\%ot lehet hangvezérléssel is irányítani 16\%-a magyar nyelvú -, viszont kevesen (17\%) használják ki ezt a lehetôséget.

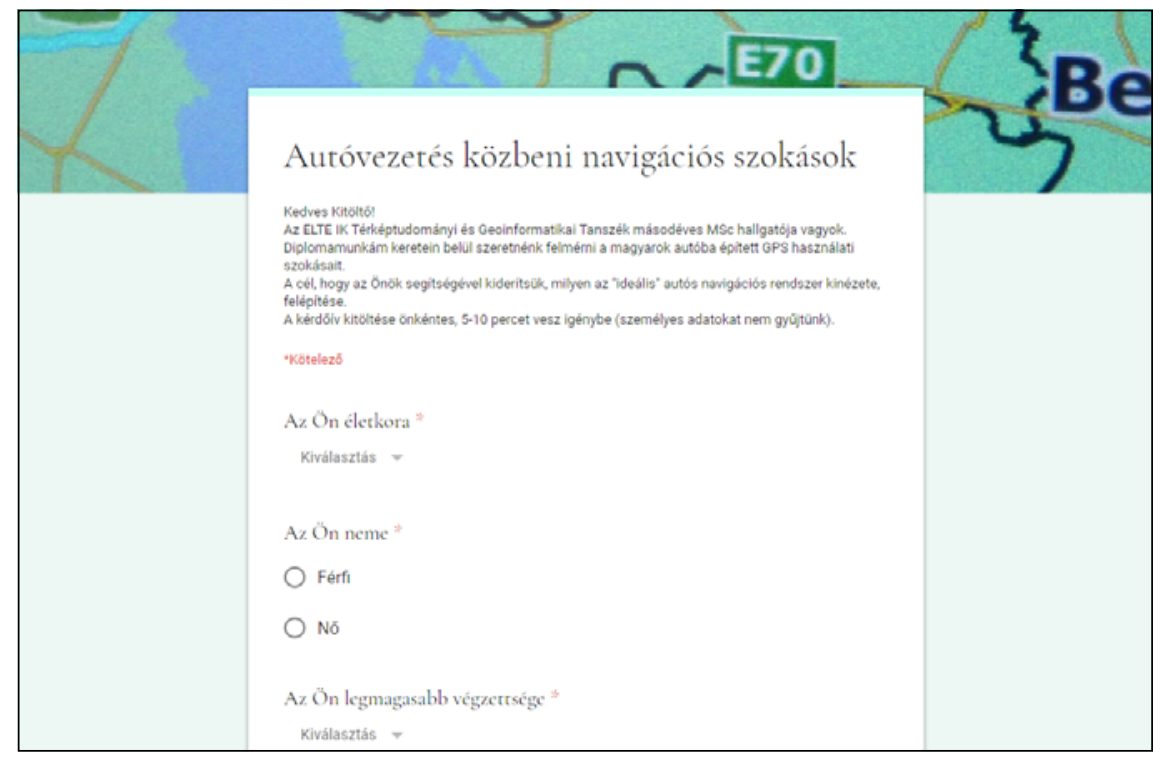

1. ábra. A kialakított Google Form kezdôképernyôje

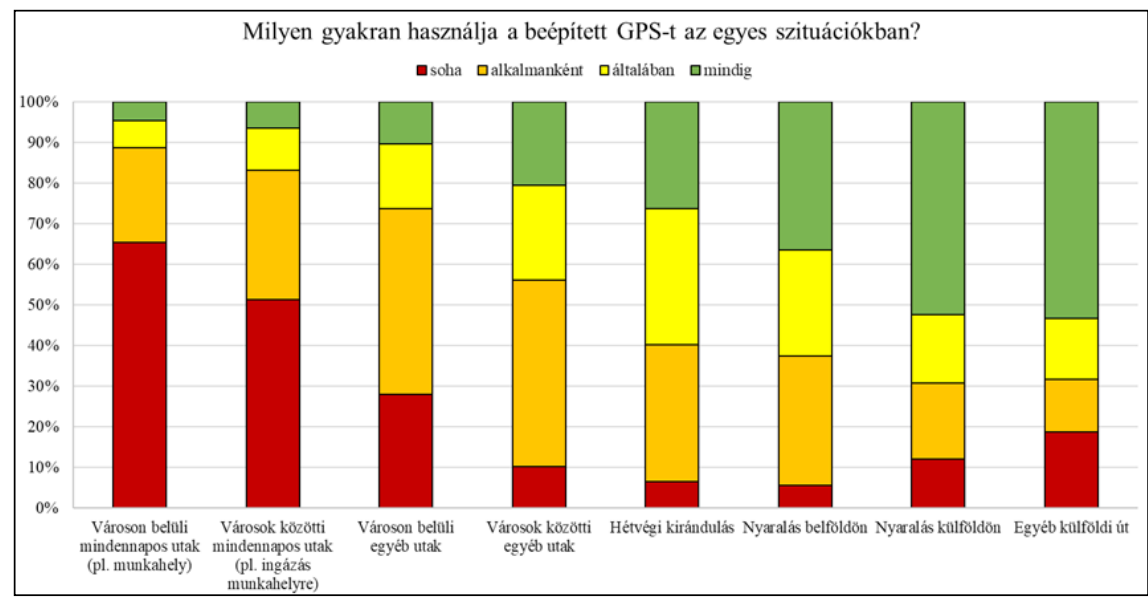

2. ábra. A beépitett eszközök használatának gyakorisága különbözố szituációkban

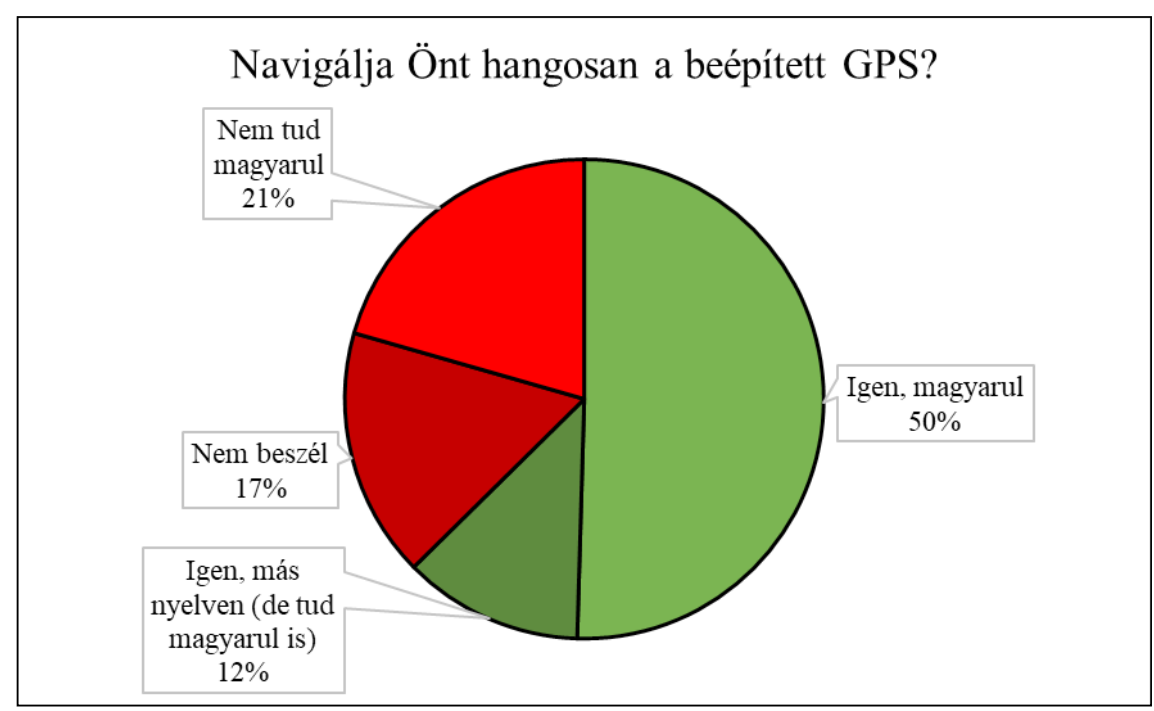

3. ábra. A beépített GPS hangutasításainak nyelve

A 3. ábrán láthatjuk, hogy a készülékek fele beszél magyarul a felhasználóhoz, a sofórök 33\%-a viszont más nyelven használja.
Érdekelt minket, hogy az autók „használtságának" van-e köze a navigációs rendszer hangutasításainak nyelvéhez - tehát például, hogy az új autókban 


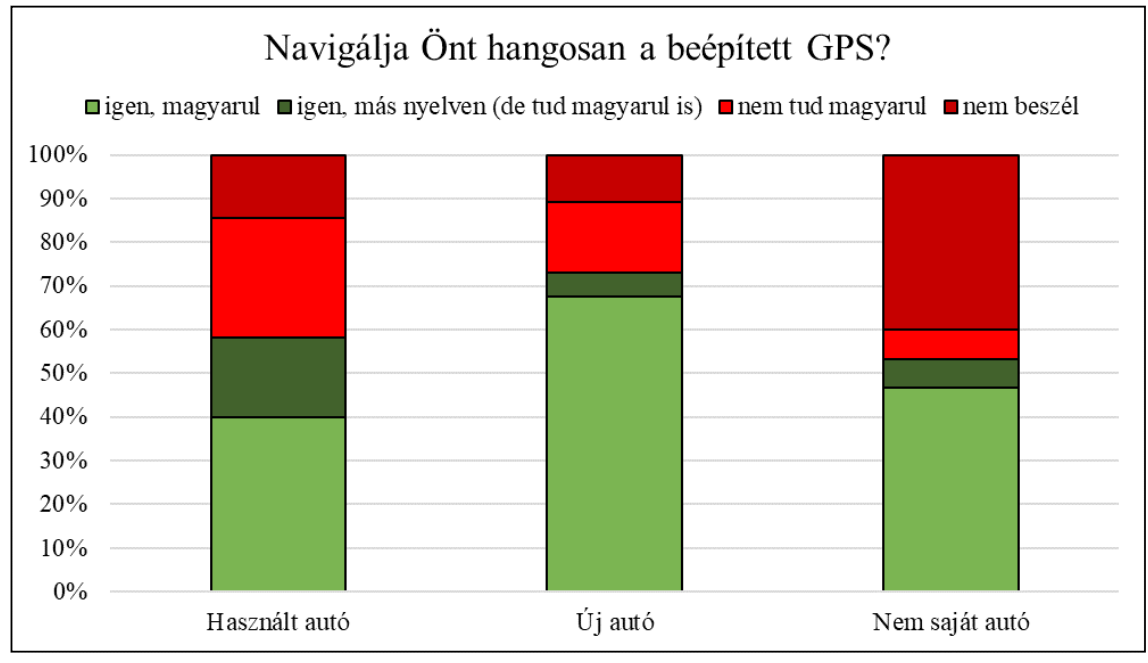

4. ábra. A beépített GPS hangutasításainak nyelve a jármü „használtsága” szerint

az eszköz inkább más nyelven beszél, mint magyarul. Rákérdeztünk arra, hogy a sofốr új autót, használtat, vagy nem sajátot vezet-e, és ezen kategóriák szerint csoportosítottuk a 3. ábrán bemutatott válaszokat (4. ábra).

Az eredményeket statisztikai próbának vetettük alá (Vörös et al. 2019), ami alapján elmondható, hogy (az általunk
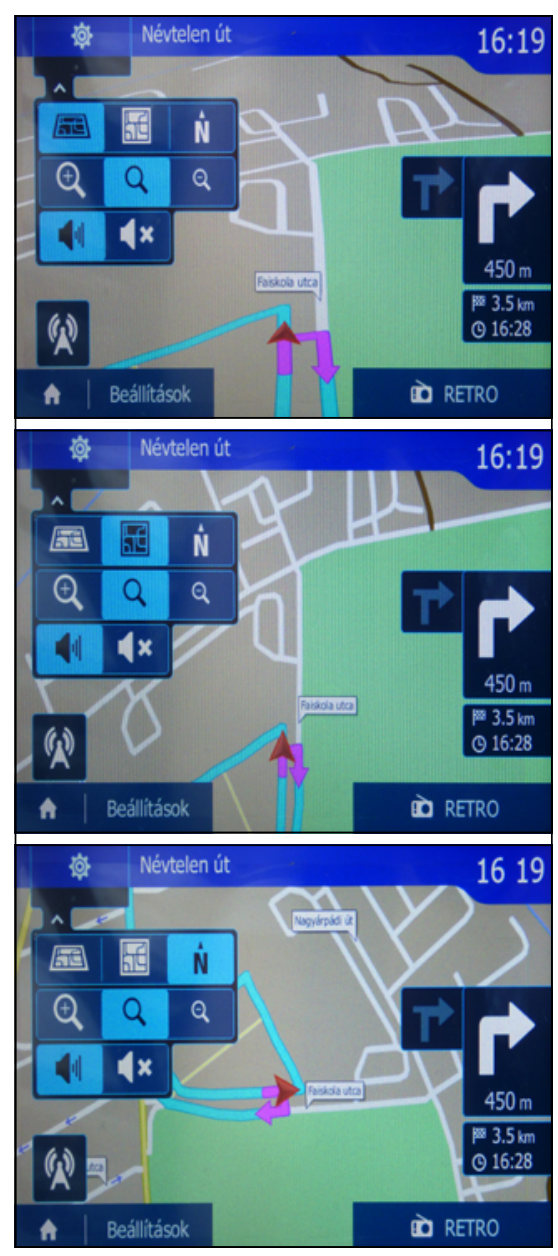

5. ábra. a) Perspektiv, b) felülnézeti, c) északra tájolt nézetek várttal szemben) egy új gépjármú GPS-e ugyanolyan valószínúséggel beszél magyarul, mint egy használté. A hangokhoz kapcsolódóan kiderült, hogy az esetek többségében (35\%) az eszközön a kattintásnak van hangja, és nem zavarja a sofôrt, $21 \%$-ban viszont igen. 31\%-ban nincs hangja, míg 13\% nem is tudta, hogy van ilyen opció.

A kitöltők nagy része a perspektív térképnézetet preferálja a felülnézetivel szemben. Mindössze 13\% használja a térképet északra tájolva, a többiek inkább menetirány szerint (5. ábra).

Kíváncsiak voltunk, hogy ha a vezetố saját maga dönthetné el, hogy hol legyen a navigációs felület, akkor hova tenné azt. Ehhez 5 lehetséges elhelyezést adtunk meg (6. ábra). Az (1)-es lehetôséget fôként a balkezesek miatt adtuk meg, mert feltételeztük, hogy egyszerúbb nekik a bal oldalon elhelyezett felületet kezelni. A múszerfalon, a kormány mögött helyeztük el a (2)-es felületet. A középkonzol tetején van a (3)-as számú, magán a középkonzolon, a „szokott helyen” pedig a (4)-es lehetôség. Az (5)-ös az üvegre kivetített felületet jelenti. Arra a kérdésre, hogy a legtöbb sofő́r hol szeretné elhelyezni a beépített navigációs felületet, érdekes módon nincs egyértelmú válasz: az egyes lehetôségen kívül (4\%) egyenlô arányban oszlanak meg a százalékok a többi 4 hely között: (2)-es 23\%, (3)-as $25 \%$, (4)-es 24\%, (5)-ös 24\%.

\section{Javasolt felület}

A kérdôívvel az volt a célunk, hogy utánajárjunk, milyen felhasználói felületet szeretnének maguk a felhasználók vagyis a sofôrök. Megadtunk lehetôségeket, amelyeket a kitöltôk bejelölhettek, hogy szeretnének, de ôk maguk is írhattak saját ötleteket. A kapott válaszok „felhasználóbarát” megjelenítésében Tompos Zoltán, az NNG Ltd. vezetô UX (user experience) tervezője segített egy mai, használatban lévő „éles” felület testreszabásával (7. ábra).

Hagyományosan a bal oldalon, felül kezdjük az olvasást, így a szemünk

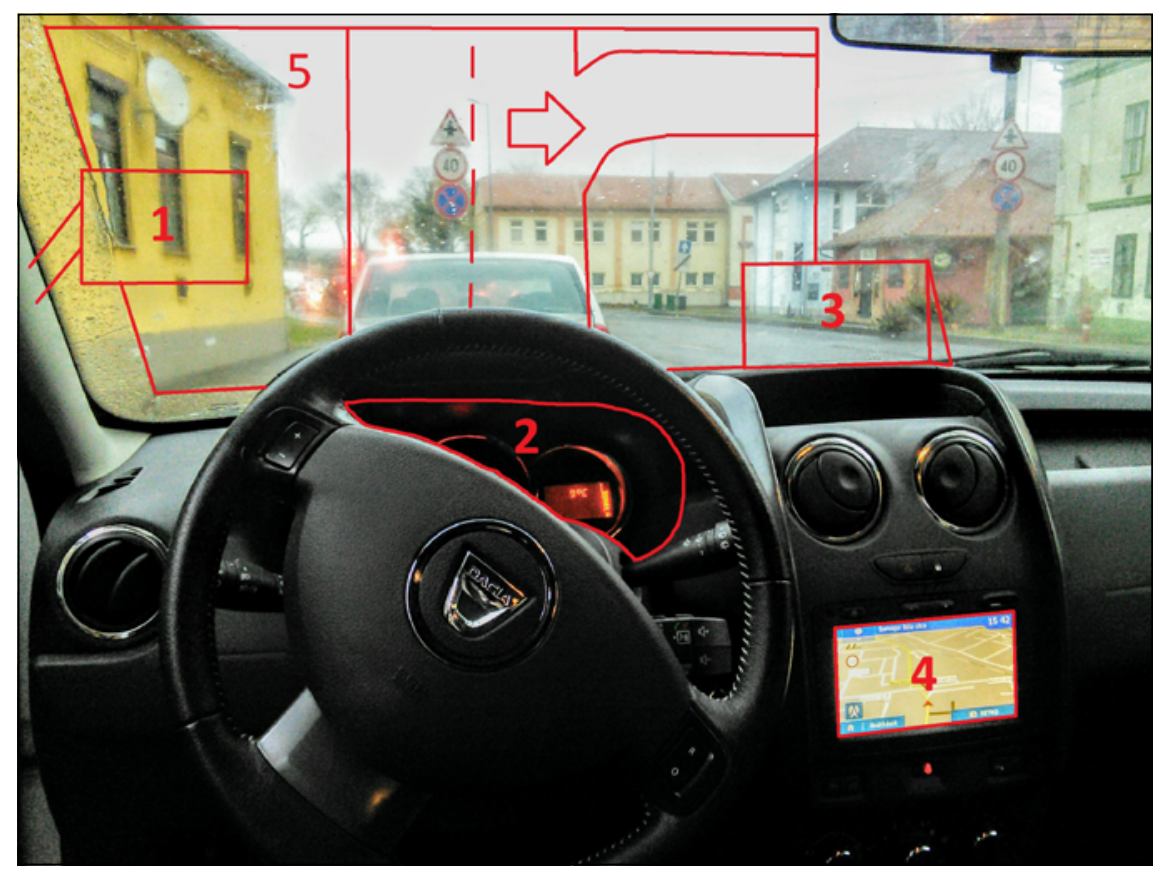

6. ábra. Lehetốségek a beépített navigáció elhelyezésére 


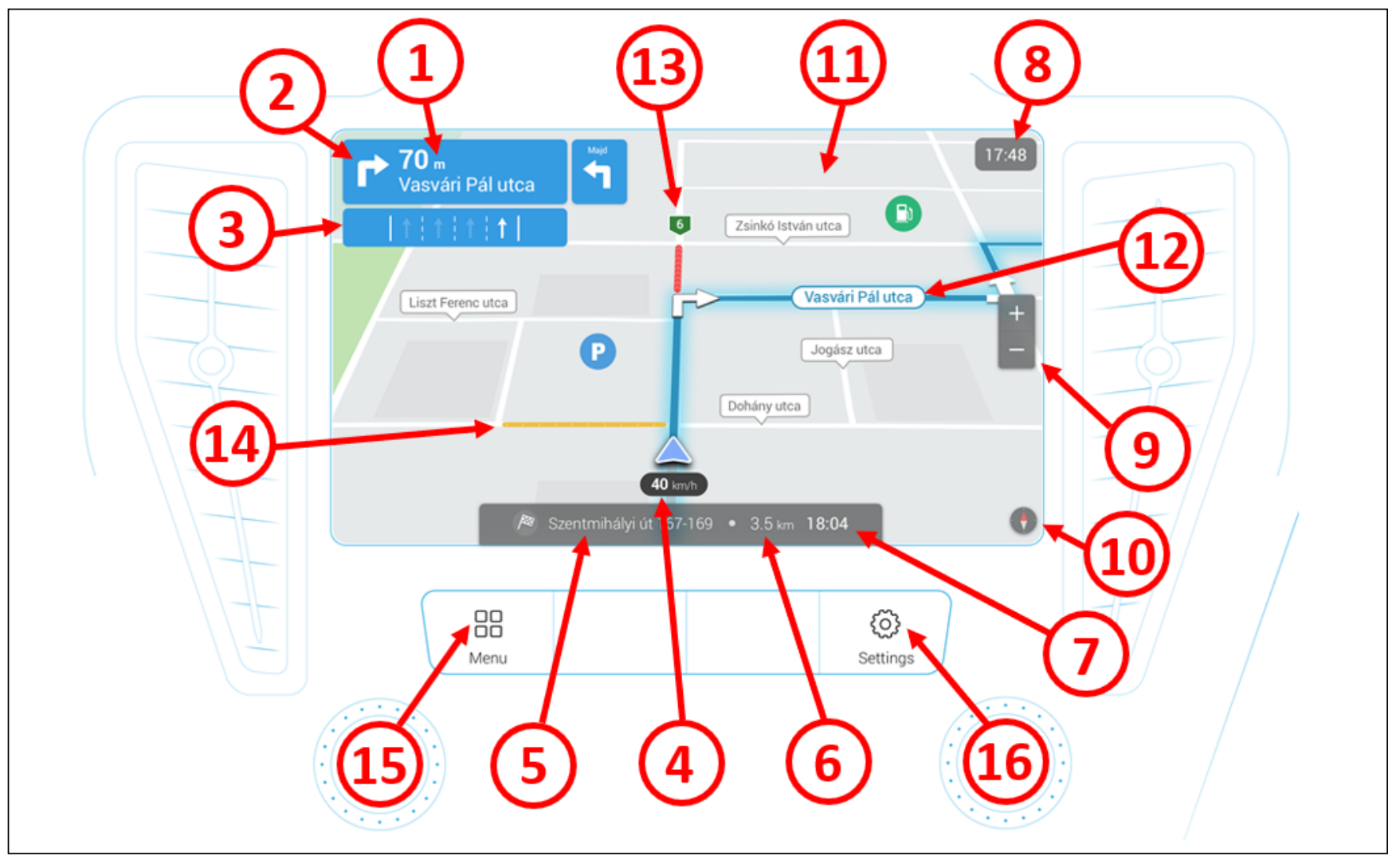

7. ábra. A beépitett GPS „ideális” felülete (Tompos Zoltán, NNG Ltd.)

automatikusan ott keresi elôször az információt. Ezen kívül, mivel a sofôr az autóban a bal oldalon ül, így a hozzá közelebb esố területeket (a képernyô bal fele) jobban látja, mint a messzebb lévőket. Ezek alapján a legfontosabb információkat a bal felsố sarokban kell elhelyezni, illetve az elóbb említett részeken. Vezetés közben a saját aktuális helyzeten kívül a leglényegesebb a következô manôver, így a forduló távolsága (1) és a fordulási irány a fordulási utcanévvel együtt (2) kerül a bal oldalon felülre. A sávinformáció (3) felugró ablakként van jelen (nincs a képernyôn rá folyamatosan szükség), és mivel szervesen kapcsolódik a soron következô manôver kivitelezéséhez, ezért közvetlenül a forduló tulajdonságai alatt található. A gépjármú helyzetét jelölő ikon középen, alul helyezkedik el, hogy a képernyốn minél „távolabbra” lehessen tekinteni; ehhez kapcsolódik a jármú sebessége (4). Az érkezési cím (5), táv (6) és idő (7) mind fontos információ, ám a sofốr maximum akkor tekint rá gyakran, ha idốre kell mennie, így középen alulra kerültek. A helyi idônek (8), a nagyítás-kicsinyítés ikonjának (9) és az iránytúnek (10) kiemelt jelentősége nincs, így félreesôbb helyekre lettek elhelyezve. A többi funkció már mind magára a térképre (11), illetve tartalmára vonatkozik; az utcaneveket (12), útszámot (13) és közlekedési információkat (14) szeretnék látni a felhasználók a GPS-ükön. A fômenü (15) és a beállítások gomb (16) általában nem magán a kijelzőn, hanem az autó középkonzolján található, így annak nyelve a gépjármútôl függ.

\section{Köszönetnyilvánítás}

Az Információs és Technológiai Minisztérium ÚNKP-19-3 kódszámú Új Nemzeti Kiválóság Programjának szakmai támogatásával készült.

\section{Irodalomjegyzék}

Al Mahmud, A. - Mubin, O. - Shahid, S 2009. User Experience with in-car GPS Navigation Systems: Comparing the Young and Elderly Drivers. In Proceedings of the 11th Conference on Human-Computer Interaction with Mobile Devices and Services (Mobile HCI 2009), DOI: https:// doi.org/10.1145/1613858.1613962

Leshed, G. - Velden, T. - Rieger, O. - Kot, B. - Sengers, P. 2008. In-car GPS navigation: engagement with and disengagement from the environment. In Proceedings of the SIGCHI Conference on Human Factors in Computing Systems (CHI '08). ACM, New
York, NY, USA, pp. 1675-1684, DOI: https:// doi.org/10.1145/1357054.1357316

The Automobile, Volume 21, Issues 19-27, Publisher Class Journal Company, 1909 Original from the University of Wisconsin Madison, Digitalizálva 2018. június 13-án

Varga, G. 2011. Navigációs rendszerek használata: felhasználói szokások és interakciók vizsgálata BME Mobil Innovációs Központ, Budapest

Vörös, F. - Tompos, Z. - Kovács, B. - 2019. Examination of car navigation systems and UX designs - suggestion for a new interface, Proc. Int. Cartogr. Assoc., 2, 139, DOI: https:// doi.org/10.5194/ica-proc-2-139-2019

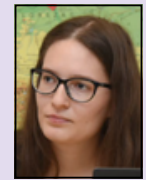

\section{Vörös Fanni} doktorandusz

ELTE Térképtudományi és Geoinformatikai Tanszék vorosfanni@map.elte.hu

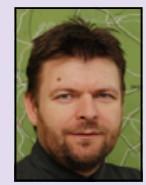

Dr. Kovács Béla adjunktus

ELTE Térképtudományi és Geoinformatikai Tanszék climbela@map.elte.hu 